Macedonian Pharmaceutical Bulletin, 66 (Suppl 1) 105 - 106 (2020)

Online ISSN 1857 - 8969

UDC: 615.262

DOI: 10.33320/maced.pharm.bull.2020.66.03.052

Short communication

\title{
The effect of Kanjiža peloid on skin hydration and skin barrier function
}

\author{
Gábor Katona $^{1}$, Slađana Vojvodić ${ }^{1}$, Marina Kalić ${ }^{1}$, Miroslav S. Sarač ${ }^{1}$, Attila Klimó ${ }^{2}$, \\ Nataša Jovanović Lješković ${ }^{1}$ \\ ${ }^{I}$ Faculty of Pharmacy Novi Sad, University Business Academy in Novi Sad, Trg mladenaca 5, \\ 21000 Novi Sad, Republic of Serbia \\ ${ }^{2}$ Special Rehabilitation Hospital "Banja Kanjiža", Narodni park bb, 24420, Kanjiža, Republic of Serbia
}

\section{Introduction}

Peloid is a mixture of mineral water, organic and inorganic substances, as a result of geological and biological processes by definition of the International Society of Medical Hydrology (Potpara et al., 2017). Due to unique characteristics, a combination of biological and chemical components, the peloid exhibited strong antibacterial and antiinflammatory effects (Devdariani and Jinchararadze, 2018; Leshchinskiı̌ et al., 1972). Also, there are evidence of peloid's positive effects on dermatological conditions such as psoriasis (Costantino and Lampa, 2005), acne and seborrhea (Szabó and Töröcsik, 2016), as well as its benefits for skincare such as cleansing, degreasing, exfoliating, hydrating, tonifying (Carbajo et al., 2010; Rautureau, et al., 2017). Therapeutic benefits of peloid are especially recognized in the field of rheumatology and dermatology.

The rehabilitation hospital, "Banja Kanjiža," has used peloid for rehabilitation treatments, and it is currently in use. This observational study aimed to determine the potential use of the Kanjiža peloid for cosmetic purposes by testing the effects of this particular peloid on skin hydration and transepidermal water loss (TEWL). There are many published literature data about the other peloids worldwide utilized for the treatment of cosmetological and dermatological conditions; however, this is the first time the Kanjiža peloid was investigated for cosmetic purposes.

\section{Materials and methods}

The peloid and thermal water used in this study were obtained from "Banja Kanjiža." The formulation of a peloid and thermal water-based cosmetic product (paste) was conducted at the Faculty of Pharmacy Novi Sad, Novi Sad, Republic of Serbia. The IRB - Ethics committee approved the research study. The research design is quantitative, quasi-experimental with pre-test, and post-test assessment and measurements.

Human subjects $(\mathrm{n}=31)$ of both genders, age 18 - 60 with all skin types, were included in the study. Exclusion criteria were: females who are pregnant or breastfeeding, those who have current active skin diseases or skin disorder in the forearms, those who are allergic/sensitive to peloid or contemporary cosmetic products. Human subjects provided their consent to participate in the study by using a signed and witnessed informed consent form strictly voluntarily and their free will. Eligible subjects were instructed not to apply any cosmetic products on

* katona.fakultet@gmail.com 
their forearm skin at least 24 hours before the study commencement.

The pre-test included skin hydration and TEWL assessment. Before the assessments being performed, the study participants acclimatized to study laboratory conditions $(40 \pm 4 \% \mathrm{RH}$ and a temperature of $20 \pm 2{ }^{\circ} \mathrm{C}$ ) for a minimum of 20 minutes. Multiprobe adapter MPA5 $^{\circledR}$ with Corneometer $^{\circledR}$ CM825 probe and Tewameter $^{\circledR}$ TM300 probe (Courage-Khazaka electronic GmbH, Germany) was used for non-invasive measurement of skin hydration and TEWL on the forearm epidermis.

The treatment conducted in this study was noninvasive: using a plastic spatula, a small amount of peloid was smeared on a $4 \times 5 \mathrm{~cm}$ surface area of the forearm skin of human subjects. The treatment ended after 30 minutes by washing off the peloid from the human subject's forearm skin.

The post-test (after 20 minutes of acclimatization to studying laboratory conditions) included the same protocol as for the pre-test: skin hydration and TEWL assessments.

\section{Results and discussion}

Corneometer $^{\circledR}$ CM825 provided us with results that show the peloid did not cause the skin to become dry ( $\overline{\mathrm{X}}$ of pre-test 30,$3 ; \overline{\mathrm{X}}$ of post-test 29,0 ; t-test 0.1774$)$. This phenomenon could be explained by the forming of a peloid shield (Carretero, 2001). Tewameter $^{\circledR}$ TM300 data, on the other hand, exhibited that the peloid caused a slight increase in TEWL values: $\overline{\mathrm{X}}$ of pre-test 8,$48 ; \overline{\mathrm{X}}$ of post-test 16,$95 ; \bar{X}$ increased $199.8 \%$, but the skin barrier function has remained without redness, irritation, and sensitivity. The exfoliating effect of the peloid could be behind this occurrence. Peloid is rich with a variety of crystal structures such as silicon and other compounds (Rautureau, et al., 2017), which possess the ability to remove dead cells layer of stratum corneum and cause the increase of the values measured by Tewameter $^{\circledR}$. This result is in correlation with literature data regarding potential the peloid's exfoliating effect (Rautureau, et al., 2017).

\section{Conclusion}

The results of this observational study exhibited that the Kanjiža peloid and thermal water are potentially suitable to be pharmaceutically and cosmetologically processed, related to the peloid's exfoliating effect and possible prevention of dehydration. The results of this preliminary observational study are contributing to further testing of this natural material, such as the effect on the amount of sebum to reveal potential anticomedogenic (Carretero, 2001) and regenerative effects of cosmetic products made explicitly from the Kanjiža peloid.

\section{References}

Carbajo, J.M., López-Delgado, M.I., Armijo, F., Maraver, F., 2010. Skin response to osmotic cosmetics elaborated with mud made from chlorided ferruginous mineral water. Presse Therm. Clim. 147, 153-154.

Carretero, M.I., 2002. Clay minerals and their beneficial effects upon human health. A review. Applied Clay Science 21(3-4), 155-163.

Costantino, M., Lampa, E., 2005. Psoriasis and mud bath therapy: clinical-experimental study. Clin. Ter. 156, 145-149.

Devdariani, N., Jincharadze, D., 2018. Use of natural peloids of Georgia for cosmecentical purposes. Organic Chem. Curr. Res. 7. 108.

Leshchinskiī, A.F., Zuza, Z.I., Barkagan, T.S., 1972. Pathogenesis of inflammation and mechanism of the anti-inflammatory action of experimental peloid therapy. Biull. Eksp. Biol. Med. 73(4), 27-30.

Potpara, Z., Pantovic, S., Duborija-Kovacevic, N., Tadic, V., Vojinovic, T., Marstijepovic, N., 2017. The properties of the Ulcinj peloid make it unique biochemical laboratory required for the treatment of problematic skin and health care. Natural Product Communications; 12, 6, $911-914$.

Rautureau, M., Figueiredo Gomes C.S., Liewig, N., Katouzian-Safadi M., 2017. External and topical applications, in: Clays and Health: Properties and Therapeutic Uses. Springer Nature Switzerland AG, pp. 154-162.

Szabó, K. and Töröcsik, D., 2016. Az acne patogenezise. Bőrgyógyászati és Venerológiai Szemle 93(3), 112120. 